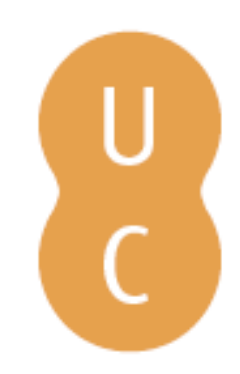

\title{
pombalina
}

\section{Fedra e Hipólito no cinema}
Autor(es): $\quad$ Rodrigues, Nuno Simões
$\begin{array}{ll}\text { Publicado por: Centro de Estudos Clássicos e Humanísticos da Universidade de } & \text { Coimbra; Imprensa da Universidade de Coimbra }\end{array}$

URL

persistente: URI:http://hdl.handle.net/10316.2/30117

DOI: $\quad$ DOI:http://dx.doi.org/10.14195/978-989-721-010-5_14

Accessed : $\quad$ 26-Apr-2023 12:09:12

A navegação consulta e descarregamento dos títulos inseridos nas Bibliotecas Digitais UC Digitalis, UC Pombalina e UC Impactum, pressupõem a aceitação plena e sem reservas dos Termos e Condições de Uso destas Bibliotecas Digitais, disponíveis em https://digitalis.uc.pt/pt-pt/termos.

Conforme exposto nos referidos Termos e Condições de Uso, o descarregamento de títulos de acesso restrito requer uma licença válida de autorização devendo o utilizador aceder ao(s) documento(s) a partir de um endereço de IP da instituição detentora da supramencionada licença.

Ao utilizador é apenas permitido o descarregamento para uso pessoal, pelo que o emprego do(s) título(s) descarregado(s) para outro fim, designadamente comercial, carece de autorização do respetivo autor ou editor da obra.

Na medida em que todas as obras da UC Digitalis se encontram protegidas pelo Código do Direito de Autor e Direitos Conexos e demais legislação aplicável, toda a cópia, parcial ou total, deste documento, nos casos em que é legalmente admitida, deverá conter ou fazer-se acompanhar por este aviso.

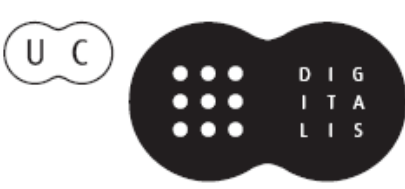




\section{Hipólito e Fedra}

\section{nos caminhos de um mito}

Carlos A. Martins de Jesus, Claudio Castro Filho, José Ribeiro Ferreira (coords.) 


\section{Fedra e Hipólito no cinema}

Nuno Simões Rodrigues

Universidade de Lisboa

São várias as adaptações do tema de Fedra e Hipólito ao cinema, embora nem sempre as personagens que nelas figuram respondam por esses nomes. Este pormenor não obsta, porém, a que o tema seja facilmente identificado, pois, como é sabido, ele é conhecido em várias culturas e mitologias antigas, sob várias formas e designações. Na própria cultura grega, essas variações estão presentes, como mostra o caso de Belerofonte (Il. 6.153-203). Na tradição oriental, podemos citar o exemplo da história de José e da mulher de Putifar (Gn 39)1 ${ }^{1}$, neste volume abordada por J. A. Ramos (pp. 72-73). Nestes casos, as formas nominais são diferentes mas a estrutura na qual reconhecemos a essência do mito de Fedra e Hipólito é a mesma. Por outro lado, o Nachleben do mito antigo foi prolífico e Racine é o exemplo mais evidente desse êxito, revelando-se determinante para a contribuição cinematográfica na composição, redefinição e divulgação do mito de Fedra e Hipólito na cultura contemporânea².

Do período do cinema mudo, conhecem-se duas versões de origem italiana: Fedra, de 1910, com Italia Vitaliani no papel titular; e Fedra. Dramma mitologico dell'Antica Grecia, uma produção de 1919. A inspiração para estas primeiras adaptações provinha sobretudo da obra de Jean Racine, escrita em 1677. Mas a mais emblemática das adaptações do tema ao cinema, aparentemente feita sobre a tragédia de Eurípides, é a de Jules Dassin. Antes da versão de Dassin, contudo, um realizador espanhol trouxe Fedra para as areias do levante ibérico, num filme simplesmente intitulado Fedra. Outras versões do mito foram filmadas com outros títulos ou motivações. Assim aconteceu com a "Fedra" de O'Neill, recriada em Desire under the Elms e levada ao cinema por Delbert Mann em 1958; e com Fedra West, uma recriação da história grega, agora localizada em Durango, no México oitocentista, em ambiente western, pela mão de Joaquín Romero em 1968. O tema é ainda reconhecido em dois outros filmes, realizados por dois dos grandes nomes da Sétima Arte: Wild is the Wind, de George Cukor, e Tribute to a Bad Man, de Robert Wise. De referir ainda a adaptação que Pierre Jourdan fez da Phèdre de Racine, em 1968, numa versão de teatro filmado. Por fim, devemos assinalar ainda a inclusão da figura de Fedra num filme de outra natureza, Teseo contro il Minotauro, um peplum realizado em 1960, cujo argumento não se centra no mito de Fedra e

\footnotetext{
${ }^{1}$ Sobre esta questão, ver M. Benavente y Barreda 1997, K. Heldmann 1968: 108-109.

${ }^{2}$ Sobre esta problemática, ver os textos reunidos por A. Pociña, A. Lopez 2008, e J. S. Lasso de la Vega 1965.
} 
Hipólito, mas no de Teseu e o Minotauro, ao qual, todavia, pertence igualmente a personagem feminina (cf. Plu., Thes. 20 e 28; Ov. Met. 497-564). Vejamos então as variações que o mito sofreu na tela. Nesta exposição e análise optamos não pela ordem cronológica dos filmes mas pela proximidade, declarada ou não, com os textos antigos, primeiro o grego e depois o latino e, finalmente, com o de Jean Racine.

\section{Melina Mercouri, Fedra para sempre}

A Fedra de Jules Dassin insere-se na corrente cinematográfica neorrealista francesa que ficou conhecida como Nouvelle Vague. O realizador, de origem estadunidense, estivera envolvido nas complexas vivências políticas do pós-guerra naquele país, no período conhecido como mccarthismo, e emigrara para a Europa, onde se casara com a atriz grega Melina Mercouri. A mesma que se viria a celebrizar no papel de prostituta do Pireu em Poté tin Kyriaki (Nunca ao Domingo, 1960), particularmente memorável na canção Ta pedia tou Pirea, e que ele haveria de escolher para protagonizar a sua Fedra.

O filme abre com um grito que funciona como som de fundo para o título. O grito anuncia a tragicidade em que o filme se baseia, ao mesmo tempo que os créditos passam sobre a imagem de baixos-relevos com a forma de cavalos, numa clara alusão à figura de Hipólito, ainda que a personagem que the corresponde não use esse nome.

$\mathrm{O}$ argumento da Fedra de Dassin foi escrito pela grega Margarita Lymberaki e assenta no enredo que motivou as tragédias de Sófocles, Eurípides e Séneca, mas também a de Jean Racine. Efetivamente, apesar de, da Antiguidade, nos terem chegado apenas uma das versões de Eurípides, o Hippolytos stephanephoros de 428 a.C., e a de Séneca, a Phaedra, sabemos que também Sófocles tinha dedicado uma tragédia ao tema. De igual modo, Eurípides teria composto uma primeira versão ${ }^{3}$, que, ao que parece, deu que falar na Atenas do século $V$ a.C. Eurípides teria sido bem mais arrojado na forma como tratara a primeira versão da sua Fedra, o que teria motivado desagrados entre a "opinião pública" e levado o poeta a reescrever o mito. Seja como for, foi o segundo desses textos euripidianos que nos chegou e que, juntamente com o de Séneca, consubstancia os argumentos do mito adaptado ao cinema.

No filme de Dassin, Thanos Kyrillis (Raf Vallone) é um quarentão rico, um armador grego que aparece como uma eventual alusão às formas de riqueza da Grécia contemporânea, que ecoavam em particular na figura de A. Onassis e no império que construiu durante o século XX. Thanos Kyrillis é por isso

3 Trata-se da Phaidra de Sófocles e do Hippolytos kalyptomenos de Eurípides. Sobre esta questão, cf. Ar., Ran. 1043-1044, e ver J. A. Segurado e Campos 1983-1984: 160, M. F. S. Silva 2005. Vd. ainda, neste volume, as pp. 116-117 e n. 4. 
uma forma moderna de rei grego e a família que vive em torno dele uma espécie de dinastia em que o dinheiro se revela um fator fulcral. Talvez por isso, Thanos chame mesmo "rainha" a Fedra, por algumas vezes. Ao longo do filme damo-nos conta de que Thanos começou por ter uma relação com Ariadne (Zorz Sarri), a filha de um outro grego poderoso, mas acabou por se casar com a irmã dela, Fedra (Melina Mercouri), uma beldade na casa dos trinta, loura de olhos profundos e semblante trágico ${ }^{4}$. $\mathrm{Na}$ verdade, Fedra é a segunda mulher de Thanos. A primeira, uma inglesa que deu ao armador um filho, vive agora no Oriente, enquanto Alexis (Anthony Perkins), o filho de vinte e poucos anos, estuda em Inglaterra. O primeiro filho de Thanos é, para alguns, uma ameaça constante à descendência que o armador tem agora de Fedra, o pequeno Dimitri (Alexis Pezas).

Este pormenor confere uma nova perspetiva ao drama, ao vinculá-lo a uma luta pelo poder. A figura que mais protege Dimitri é provavelmente Ana (Olympia Papadouka), a ama, que já fora de Fedra, cuja existência silenciosa não é suficiente para passar despercebida na vida dos Kyrillis. É a ama, por exemplo, que na sequência de uma perceção adverte Fedra para que desista da viagem que pretende fazer a Londres, com o objetivo de convencer o enteado a visitar a Grécia e a casa do pai ${ }^{5}$. Thanos quer aproximar o filho primogénito da sua nova família e acredita que a forma mais eficaz de o fazer é enviando a madrasta ao encontro do enteado. Mas o que Thanos de facto faz é funcionar como catalisador do destino para a concretização da tragédia que se anuncia. Alexis estuda economia em Londres, contudo a verdadeira paixão do rapaz é a pintura e a arte em geral, o que aliás incomoda o pai, mas que é evidência da sensibilidade que domina o espírito de Alexis. Esta faceta do jovem equivale às opções religioso-alimentares do Hipólito euripidano (Eur. Hipp. 936-981). Ao mesmo tempo, este caráter contrasta com a paixão que o jovem demonstra ter por automóveis e que acrescenta uma certa dose de futilidade à sua sensibilidade de artista. Os dias de Fedra e Alexis em Londres permitem que a paixão germine entre madrasta e enteado, o que leva Fedra a cometer loucuras, como a oferenda de uma joia valiosa ao Tamisa, evocativa dos antigos sacrifícios gregos, em troca de um desidério para que o rapaz visite a pátria paterna.

A paixão acaba por se consumar em Paris, onde Thanos e Fedra se encontram com Alexis, num luxuoso apartamento da família. O pai acaba por deixar madrasta e enteado, por mais uma reunião de negócios, apesar dos

\footnotetext{
${ }^{4}$ Este pormenor é importante, dado que Fedra é caracterizada no texto de Eurípides como loura (cf. Eur. Hipp. 220).

${ }^{5} \mathrm{O}$ caráter mântico da ama aparece em vários dos filmes e inspira-se por certo na figura da ama antiga (e.g. Eur. Hipp. 508-515).
} 
pedidos desesperados de Fedra para que fique, pois pressente que a fraqueza acabará por se revelar. Fedra e Alexis caem nos braços um do outro, ela atraída pela juventude e pureza do enteado, ele dominado pela maturidade da mulher, quiçá representação e imagem de uma mãe ausente. $\mathrm{O}$ adultério acontece, na pior das suas formas, resvalando o incesto. A perceção do êxtase de Alexis é um dos momentos mais bem conseguidos de todo o filme, ao nível estético, valendo mais do que qualquer imagem explícita. A paixão de Fedra é representada sobre a imagem do fogo da lareira que arde ao fundo, oferecendo um enquadramento para as emoções que se pressentem. Por momentos, vislumbra-se a estátua de Afrodite, personagem que aqui é sobretudo uma força psicológica, tal como Ártemis o é em relação a Alexis (K. MacKinnon 1986: 103) ${ }^{6}$. Por isso, em parte, é Eurípides quem dirige a cena, ainda que a consumação do adultério lhe seja estranha. A música de Theodorakis, em que predomina um tom etnicamente helénico, faz o resto... A cena culmina com um significativo agapi mou, proferido por Fedra, e numa canção grega de tonalidades trágicas, igualmente cantada pela personagem feminina e que funciona como substituto das antigas odes trágicas.

Fedra e Alexis vivem a sua história de amor no apartamento de Paris. A ausência de Thanos e dos restantes membros da família cria a ilusão de que tudo é possível, que o sonho poderá tornar-se realidade. Mas um telefonema de Thanos põe termo à aventura e à utopia. Fedra desperta da sua letargia, o que encoraja Alexis a sugerir a fuga dos amantes. Fedra, porém, resiste à tentação. De regresso à realidade, a grega acaba por voltar para a Grécia, enquanto Alexis retorna a Inglaterra. Aos poucos, a paixão do enteado pela madrasta vai dando lugar ao ódio e é este que acaba por se impor, configurando a faceta determinada pela rejeição de Fedra.

Uma vez na Grécia, a família recolhe-se na casa que possui na ilha de Hidra. Fedra sofre a paixão em silêncio, com a cumplicidade tácita da ama. Vários planos sugerem que o amor de Ana por Fedra vai além do sentimento maternal ou fraternal. Há algo de homoerótico na forma como Ana olha Fedra, como sofre por ela ou com ela. A personagem define-se por um misto de afeto maternal e afetividade sáfica. Esse homoerotismo haverá de confirmar-se na cena do suicídio da madrasta, com o beijo que a serva deposita nos lábios da sua senhora.

Por fim, Thanos consegue que Alexis visite a Grécia e Fedra manifesta sentimentos ambíguos em relação à chegada do enteado. A ansiedade por voltar a vê-lo é grande, mas ao mesmo tempo o medo apodera-se dela. Estes sentimentos porém revelam-se despropositados quando Alexis chega, pois o jovem assume uma postura de desprezo pela madrasta. Até então reservado

\footnotetext{
${ }^{6}$ Sobre o papel das deusas na tragédia antiga, ver M. C. Fialho 1996.
} 
em relação ao amor, Alexis mostra-se agora mais do que nunca interessado em descobrir os prazeres do coração. A "prima” Ercy, filha de Ariadne e sobrinha de Fedra, começa a demonstrar interesse pelo rapaz e todos, à exceção de Fedra, vislumbram um oportuno casamento de sonho para os dois jovens. A união de Alexis e de Ercy significaria um reforço do poder de ambas as famílias. Por momentos, Ercy reivindica as funções que Ártemis tem no mito grego, ainda que não exclusivamente, centrando as atenções do jovem. A união com Ercy daria mais força à tragédia familiar. Mas Alexis é um jovem inglês à descoberta do verão mediterrâneo, tópico aliás comum nas culturas do Norte da Europa, na qual o mar do Sul exerce um fascínio particularmente intenso. Ali, tudo para Alexis é sinónimo de liberdade, descoberta e aventura. Ercy não lhe chega e a sua atenção cai sobre outras raparigas também. Os sentimentos para com a madrasta baralham-se, oscilando numa escala definida pela paixão e pelo ódio. Também o ciúme de Fedra vai crescendo e o anúncio de um eventual casamento com a sobrinha despoleta a necessidade de revelação do até então inominável: Fedra e Alexis são amantes. O confronto entre madrasta e enteado acontece no pátio interior da casa. Mas a revelação far-se-á apenas no escritório de Thanos. E o momento escolhido não é o melhor: aconteceu um naufrágio, o do navio Phaedra, cujo batismo servira de mote de abertura do filme ${ }^{7}$. O pressentimento da existência de vários mortos entre a tripulação instala-se. As mulheres dos marinheiros esperam notícias na empresa de Thanos. Vestidas de negro, anunciam já a desgraça. O Phaedra é uma metáfora da protagonista da história. Também a sua vida se afunda. Fedra entra no escritório do marido, alheada e egocentrada, completamente vestida de branco, em contraste com as aldeãs que evocam o coro trágico, chamado à cena pelo acontecimento que assinala e em parte desencadeia a metabole trágica ${ }^{8}$. Uma espécie de metáfora de uma maldição nemésica. A madrasta, porém, está decidida a revelar ao marido a conspiração amorosa com o enteado. A consumação do adultério incestuoso não permite a mentira das versões antigas do mito. A revelação é aqui a verdade e a confissão do adultério substitui o motivo do bilhete da tragédia antiga. Esta Fedra, porém, está longe da de Eurípides, que prefere morrer a revelar a sua paixão pelo enteado.

Ela tenta assim evitar o casamento do jovem com a sobrinha. Significa isso que, para esta Fedra, o seu drama familiar é superior ao das mulheres que se encontram ao seu lado. A sua paixão é mais forte do que a perda de

${ }^{7} \mathrm{O}$ navio é referido no filme por duas vezes como o 'monstro do mar', o que remete para a imagem do touro ou do Minotauro, criatura localizada para além do mar da Ática e que funciona como motivação para a viagem iniciática de Teseu.

${ }^{8}$ As mulheres vestem um traje típico da cultura mediterrânea, de que se destacam o negro e a cabeça coberta. O lamento das mulheres que choram os familiares perdidos no naufrágio remete para os coros de lamentação da tragédia grega. 
vidas humanas, magistralmente evocadas através da lista de nomes gregos que se ouve em tom de fundo, ao mesmo tempo que a protagonista aparenta ignorá-los. Nada mais importa para Fedra, o que acaba por constituir uma espécie de hybris, de arrogância trágica por parte da personagem. Dassin opta assim por sobrepor tragédia a tragédia, drama privado a drama público, relativizando uma em relação à outra, com ecos diferentes nos seus recetores, consoante se trate das personagens ou dos espectadores. A intensidade de cada uma delas depende dos seus protagonistas. Igualmente pertinente é o facto de a morte dos marinheiros contrastar em absoluto com a de Fedra e Alexis, sendo a primeira involuntária e indesejada e a segunda voluntária e almejada. Talvez seja possível descortinar aí algo da ideia de liberdade, inexistente para os primeiros, presente nas atitudes dos segundos, pois apesar de a paixão descontrolada ter dominado o final das suas vidas, as escolhas dos caminhos a seguir acabaram por ser apenas da sua responsabilidade.

Fedra/ Mercouri é magnífica, mesmo sob o efeito da desgraça. Feita a revelação, tudo se precipita. Thanos, que se refere a si próprio como um touro, agride o filho, que sai transtornado do escritório do pai. O rapaz entra no carro que o progenitor lhe oferecera e acaba por cair numa das ravinas da ilha, gritando o nome da amante. O Aston Martin acaba por funcionar como o ataúde do jovem. A morte de Alexis deixa um sabor de ambiguidade para quem assiste, ficando indefinido se a mesma ocorre em consequência de um acidente ou de um suicídio, se a madrasta é para ele objeto de ódio ou de paixão. A diferença entre ambas, porém, é mínima. Mas fica claro que a sua morte foi motivada pelo confronto com o pai. Por sua vez, Fedra abandona o escritório e, uma vez em casa, suicida-se, com recurso ao veneno. Apenas a fiel ama está com ela. A tragédia consuma-se9.

Como facilmente se percebe, os vetores sobre os quais assenta o argumento desta Fedra são os mesmos que constituem os dramas clássicos. O triângulo formado por Thanos/ Fedra/ Alexis corresponde ao das figuras de Teseu/ Fedra/ Hipólito. O drama familiar está no centro de tudo. Daquelas, apenas Fedra mantém o nome na versão cinematográfica. Há ainda Ariadne que, apesar de não pertencer ao núcleo de personagens da tragédia antiga, fazia parte do ciclo mitológico de Teseu, tal como as restantes, aliás.

Mas há outras metáforas a levar em consideração. No caso de Alexis, as constantes alusões ao cavalo e à estreita relação entre a personagem do filme e o animal remetem para o nome da figura mitológica (Hippo-lytos = "aquele

\footnotetext{
${ }^{9}$ Cabe aqui referir que em nenhuma das produções cinematográficas que optam pela morte de Fedra no final se recorre ao tema da espada, aspeto salientado pelo estudo de J. A. Segurado e Campos 1983-1984, e apenas a película baseada na peça de O’Neill sugere a forca como castigo.
} 
que solta os cavalos" ou "aquele que é despedaçado pelos cavalos (?)" $)^{10}:$ o baixo-relevo com representações de cavalos, a pulseira de cavalos, a visão em que a ama vê Alexis ser pisado por cavalos, o motor do veículo cuja potência é avaliada em cavalos, etc. $\mathrm{O}$ primeiro encontro entre enteado e madrasta acontece na sala dos mármores de Elgin, no Museu Britânico, dos quais se destacam as cabeças dos cavalos de Hélio e de Selene, nas extremidades do tímpano de um dos frontões do Pártenon. Alexis desenha a cabeça de um dos cavalos. $\mathrm{O}$ enquadramento desta cena é simultaneamente uma alusão à natureza e raiz grega da personagem de Alexis/ Hipólito e uma homenagem à pátria de Mercouri. A sensibilidade artística de Hipólito, que prefere a pintura à economia, corresponde à figura do jovem casto dedicado a Ártemis, que afasta de si o culto de Afrodite. A paixão pelas artes equivale a uma espécie de inocência em relação ao cruel e frio mundo das finanças e do dinheiro, que domina a vida da família do seu pai, mas que ao mesmo tempo é a garantia que assegura a sua educação numa escola de elite em Londres. É este conjunto de elementos, a que se junta a imagem de "doce pássaro da juventude" do enteado, que perturba a sanidade passional da madrasta. É portanto evidente que o caráter desta personagem baseia-se nas particularidades do Hipólito euripidiano.

Por outro lado, é uma imagem de Afrodite que, no mesmo museu, parece sufocar Fedra, numa alusão ao papel que a deusa tem na tragédia de Eurípides, sobretudo, enquanto força determinante no curso dos acontecimentos ${ }^{11}$. Tal como no trágico grego, a paixão apodera-se de Fedra e torna-se incontrolável. Mas o elemento divino foi agora desconfigurado, passando toda a responsabilidade para o arbítrio de Fedra.

O sogro de Thanos corresponde à figura de Minos, rei de Creta; o cunhado à de Dioniso, o deus que acabou por desposar Ariadne na antiga tradição; e a mãe de Alexis à de Antíope, Hipólita ou Melanipe, a rainha amazona que dera um filho a Teseu ${ }^{12}$. A personagem da Ama é naturalmente uma recuperação da figura da tragédia euripidiano-senequiana. Já Ercy é uma criação original do argumento da escritora Margarita Lymberaki, eventualmente derivada da

${ }^{10}$ A seguirmos as leituras feitas por Vergílio (Aen. 7.767) e Ovídio (Fast. 3.265), o nome da personagem deverá ser entendido como "aquele que é despedaçado pelos cavalos". Mas a sua forma grega sugere uma composição a partir do verbo lyo, que significa "soltar" ou "desligar". Sobre esta problemática, ver M. Paschalis 1994: 119. Seja como for, a associação do animal à personagem é claramente apreendida pelos realizadores de cinema.

${ }^{11}$ Sobre esta questão, ver M. F. S. Silva 2005, F. Lourenço 1996: 11-13.

${ }^{12}$ As alusões a esta personagem nos textos antigos deixam transparecer alguma dialética entre as ideias de grego/ bárbaro, sendo a amazona apresentada com um figurino estrangeiro. As adaptações cinematográficas tendem a manter essa definição. No filme de Dassin, por exemplo, verifica-se uma antinomia entre o caráter impulsivo dos Gregos e uma certa frieza britânica, que se sugere bizarra aos do Sul. 
leitura raciniana e da personagem de Arícia $^{13}$. Por conseguinte, a proposta de Lymberaki baseava-se não só nas tragédias antigas, mas também na estrutura do mito de Teseu, igualmente talassocêntrico ${ }^{14}$.

Por outro lado, no filme de Dassin, Fedra é efetivamente o centro do enredo, o que de certo modo remete mais para o texto de Séneca do que o de Eurípides ${ }^{15}$. Outra diferença assinalável é o facto de o enteado repelir a madrasta após a consumação do amor, havendo um crescendo em dialética entre paixão e ódio apenas a partir desse momento. Com efeito, é à medida que a narrativa avança que a Fedra de Jules Dassin se vai assemelhando cada vez mais à heroína antiga.

Outras referências remetem eventualmente para aspetos da cultura grega, como a alusão às Olympic Airlines que transportam as personagens do filme, talvez metáfora dos deuses olímpicos, que, ao contrário do que acontece no filme, na versão de Eurípides têm um papel fundamental no enredo. $\mathrm{Ou}$ ainda a comparação do carro de Alexis com os cavalos que no mito estarão na base da sua morte. A simplicidade da casa tipicamente mediterrânea dos Kyrillis em Hidra evoca a austeridade da cena ática. $\mathrm{O}$ concurso de pratos lembra o espírito agónico dos Gregos. A máscara que vemos ao fundo do quarto, na cena da morte de Fedra, é uma referência inequívoca à tragédia grega.

Apesar deste conjunto de referências, várias foram as críticas à Fedra de Dassin. O. Taplin chegou a afirmar que este filme não merecia qualquer comentário, em grande parte devido à reconfiguração da personagem de Hipólito que aqui prescinde do seu ascetismo, essencial à definição da tragédia antiga ${ }^{16}$. A própria Mercouri tê-las-á feito, considerando que a tragédia falhou como projeto, dando lugar a um drama familiar de cariz burguês ${ }^{17}$. Isto porque o elemento divino transcendente ao arbítrio das personagens que condiciona o percurso dos acontecimentos na tragédia antiga, como são a rivalidade entre Afrodite e Ártemis e o consequente destino das figuras de Fedra e Hipólito que não prescindindo do seu estado de inocência são apanhadas no turbilhão fatal provocado pelas incompatibilidades divinas -, acabou por ser substituído pela moralidade da família dita burguesa do século XX em que, acima de tudo,

${ }^{13} \mathrm{O}$ nome desta personagem relaciona-se com passos de Verg. Aen. 7.765-770, e de Ov. Met. 15.488, que relacionam a cidade e vale de Arícia com Hipólito.

${ }^{14}$ Sobre esta questão, ver Plu. Thes., passim.

${ }^{15}$ Sobre estas diferenças e problemáticas ver, entre outros, M. McDonald 1983: 89-127, J. A. Segurado e Campos 1983-1984, M. C. Pimentel 1987, F. B. Santos 1988, J. B. T. Prado 1995, N. Llagüerri Pubill 2010.

16 Apud K. MacKinnon 1986: 101. Ver ainda a crítica de B. F. Dick 1962.

17 Apud K. MacKinnon 1986: 98-99. A este propósito, cabe referir que o bürgerliches Trauerspiel, como Lessing lhe chamou, não deixa de ser uma proposta de tragédia. Cf. J. P. Serra 2006: 42-43. 
há comportamentos que "ficam mal" por transgredirem os vínculos familiares e infringirem as regras sócio-morais ${ }^{18}$.

\section{Fedra em praias de Espanha}

O filme que o realizador galego Manuel Mur Oti dirigiu em 1956 é assumidamente baseado na tragédia de Séneca ${ }^{19}$. Apesar de se tratar de uma produção mais antiga do que a de J. Dassin, o texto que parece ter estado na base do seu argumento, escrito pelo próprio Mur Oti, é o mais recente dos dramas escritos na Antiguidade sobre o tema de Fedra e Hipólito. A escolha de Séneca talvez se tenha devido à importância do autor hispânico para a cultura espanhola, que desse modo poderia evocar o Cordubense como seu "antepassado cultural". Para mais, há que não esquecer que, apesar de o realizador não ser identificado com o regime, estava-se em pleno Franquismo, para o qual esse pormenor era significativo ${ }^{20}$.

A ação é transportada para Aldor, uma aldeia de pescadores no Levante espanhol, o que não deixa de evocar as raízes clássicas do território em questão $0^{21}$. Ulisses teria sido um dos seus visitantes (cf. F. Salvador Ventura 2008: 505). Mas a quem não se apercebe de imediato dessa conexão é oferecida uma imagem com uma estátua de Afrodite, bem como um cenário em que se vislumbram colunas gregas sobre um promontório ${ }^{22}$. O ambiente clássico está criado. Seja como for, a técnica que consiste em atualizar as formas de apresentação de um texto antigo não é rara e Mur Oti repete-a nesta Fedra.

A Fedra de Mur Oti chama-se Estrela (Emma Penella) e, fazendo jus ao seu nome, é a mais bela mulher de Aldor, cobiçada por todos os homens da aldeia. É por isso vista como vaidosa, altiva e soberba, condições que permitem vislumbrar nela a hybris trágica e o que provoca o ciúme nas outras mulheres da praia. A beleza de Estrela é desde o início prenunciadora da tragédia iminente e aquelas não hesitam em associar a figura da rapariga ao Diabo, o que é um topos reconhecível em vários textos e adaptações cinematográficas. A título de exemplo, poderíamos citar O Crime da Aldeia Velha, levado ao cinema por

18 Eventualmente, poderíamos afirmar que estamos perante uma reformulação contemporânea da ideia de "trágico". Cf. J. A. Segurado e Campos 1983-1984: 164-165.

${ }^{19}$ Como nota F. Salvador Ventura 2008, a fita de Mur Oti é frequentemente ignorada nas listagens de filmes dedicados ao tema.

${ }^{20}$ Sobre o realizador, F. Salvador Ventura 2008: 505-506 nota que Mur Oti não pode ser classificado como alguém que defendesse os valores do regime franquista, mas que também não era propriamente um contestatário declarado. Deverá ser, portanto, um intelectual moderado. Ainda assim, considera-se este Fedra um filme transgressor se se tiver em conta a época da sua produção. No mesmo artigo, ver acerca das vicissitudes do filme com a censura espanhola.

${ }^{21}$ Aparentemente, a aldeia fictícia de Aldor localiza-se perto de Valência.

${ }^{22}$ Sobre as possíveis conexões com o templo de Posídon no cabo Súnio, ver F. Salvador Ventura 2008: 512. 
Manuel Guimarães em 1964, baseado na peça teatral homónima de Bernardo Santareno ${ }^{23}$.

Ao contrário do mito grego original, esta Fedra não é uma princesa, no sentido aristocrático do termo, ainda que o casamento venha a elevar o seu estatuto social na comunidade em que está inserida. $\mathrm{Na}$ verdade, o realizador espanhol cria um passado distinto para a sua Fedra. Estrela vive com o pai, um velho cego (Manuel de Juan) - eventual evocação do mito de Tirésias - e faz colares de conchas - possível referência a Afrodite - que vende no único estabelecimento comercial da aldeia para sobreviver. Mas até esse recurso se transforma num obstáculo no momento em que o dono da loja assedia Estrela, que o rejeita. Vicente (Raúl Cancio), o comerciante, torna-se doravante um aliado da irmã, Rosa (Porfiria Sanchiz), uma das mulheres da praia que emerge qual harpia ou fúria e que parece funcionar como corifeu do coro de Aldor (F. Salvador Ventura 2008: 511).

Um dia, Estrela conhece D. Juan (Enrique Diosdado), um viúvo rico, armador do Norte, que chega a Aldor e se enamora da jovem. O encontro de D. Juan com Estrela sugere de novo uma composição afrodisíaca: Estrela aparece-lhe emergindo do mar, como se fosse uma nereide ou a própria Afrodite que, convém recordar, é a deusa diretora destes acontecimentos na tragédia antiga. O erotismo domina toda a cena. D. Juan instala-se na aldeia, investindo em Estrela. Esta gosta dele mas não o ama, pelo que D. Juan tem esperança de que ainda assim ela venha a aceitar casar-se com ele.

Entretanto, Estrela conhece Fernando (Vicente Parra), um jovem amante dos cavalos, que detesta o mar, a praia e até mesmo o sol, preferindo os campos, as serras e as árvores. Fernando reúne todas as características para configurar a personagem de Hipólito. Além do já enunciado, ele é filho de Juan. Estrela enamora-se profundamente de Fernando mas este despreza-a. Em Fernando há mesmo traços de uma postura homofílica que se coaduna com a rejeição de Estrela e que, ao mesmo tempo, está de acordo com vetores que definem a personagem de Hipólito, na sua vertente misógina, tal como aparece em Eurípides e em Séneca. Se Estrela é desejada por todos os homens, porque a despreza Fernando? Só nos ocorre uma resposta... A confirmar-se esta leitura, contudo, ela apenas se pode fazer através do enredo de insinuações, pois seria difícil expor de forma clara uma temática desta natureza no cinema espanhol dos anos $50^{24}$. Nem a tensão erótica que se instala na casa de D. Juan no momento em que ele deixa o lar para partir em missão comercial consegue

\footnotetext{
${ }^{23}$ A este propósito, recorde-se o momento da queima da bruxa que, no filme espanhol, se aproxima da temática da produção portuguesa. Também o filme Susana (1951), de Luís Buñuel, recupera o tema da rapariga que "encarna" o demónio.

${ }^{24} \mathrm{Na}$ verdade, seria difícil expô-la em qualquer cinematografia conhecida dessa época.
} 
evitar que sobre Fernando caia a suspeita da sua homossexualidade. Ao invés. O incómodo é visível no jovem, que se sente oprimido pelo facto de agora, mais do que nunca, ser o centro das atenções da recém-madrasta. E mais do que um eventual dilema de identidade no espírito do rapaz, o momento em que ele observa Estrela tomando o seu banho, numa cena de claros ecos míticos (tema de Actéon) e herodotianos e bíblicos (designadamente dos episódios de Candaules e de David e Betsabé e de Susana), deverá significar sobretudo a ameaça da opressão sobre a sua liberdade existencial, i.e., da sua orientação sexual ${ }^{25}$. A confissão do asco que sente pela madrasta comprova-o e a suposta homossexualidade torna-se aqui metáfora da castidade entregue a Ártemis. A este propósito, há que recordar que os autores antigos, designadamente Séneca, sugeriam o homossexualismo como fazendo parte do perfil quer de Hipólito, através da sua misoginia, quer de Teseu. Com efeito, esta faceta corresponde à misoginia do Hipólito antigo, em particular o do dramaturgo latino ${ }^{26}$.

A figura de Fernando, louro, vestido de branco e montado sobre um cavalo da mesma cor, qual metáfora da inocência do rapaz, destaca-se no horizonte da praia de Aldor e Estrela torna-se incapaz de controlar a paixão pelo jovem. Doravante, o comportamento de Estrela assemelha-se ao de uma criança rejeitada e imatura. É o ciúme que a consome. Apesar de detestar o sol, as cores que dominam Fernando associam-no à luz, de certa forma indicadora dos valores do Hipólito de Eurípides e de Séneca, por oposição aos dos animais que se revelarão seus opositores: o touro e o cavalo ${ }^{27}$. De igual modo, tal como acontece com o filme de Dassin, um conjunto de símbolos visuais contribui para essa identificação, como a presença dos cavalos ou a estatueta com a forma desse animal colocada junto à fotografia que Fernando tem no quarto.

Já o recurso à caracterização de Estrela envergando um vestido branco que contrasta com o negro das mulheres da praia, e que reconhecemos no filme de Dassin, aparecia já na película de Mur Oti. Outros símbolos caracterizados como "metáforas visuais" reconhecem-se noutros domínios, como a presença do mar e da tempestade, o locus horrendus, que voltam a ser um elemento fundamental nesta composição, ou a do castelo, que simboliza o palácio real da antiga tragédia (cf. F. Salvador Ventura 2008: 511).

${ }^{25}$ Ver Ov. Met. 3.131-252; Hdt. 1.7-13; 2Samuel 11; Daniel 13.

${ }^{26}$ Cf. Eur. Hipp. 616-634; Sen., Phaed. 244, 566-579; Ov., Her. 4.109-112; Ver J. A. Segurado e Campos 1983-1984: 158, 166, que nota que o "Hipólito de Eurípides revela-se misógino depois de saber da paixão de Fedra, o de Séneca, mesmo antes de suspeitar do caso". O mesmo autor refere que a misoginia do Hipólito senequiano não é mais do que a contrapartida das inúmeras aventuras amorosas de Teseu. Nem sempre é assim nas versões cinematográficas. Eventualmente, sê-lo-á na adaptação de O'Neill/ Mann.

${ }^{27} \mathrm{O}$ recurso à imagem destes animais para construir o mito está presente logo nos textos antigos e foi consecutivamente transportada para a tela. Sobre o simbolismo do cavalo e do touro no mito em questão, ver M. Paschalis 1994. 
Neste filme reconhecemos também vias de aproximação aos formalismos da tragédia grega, como a presença do coro, que se define através do grupo de mulheres da aldeia, chefiadas pela irmã do comerciante local e principal instigadora do ódio sobre Estrela. Por outro lado, há personagens do mito original que aparecem noutras produções e que aqui estão ausentes, como Ariadne; e Antíope/ Hipólita/ Melanipe é aqui apenas uma memória.

Tal como o fado, o flamenco tem sido evocado como uma forma ibérica de expressão cultural associada aos temas do destino, do fatalismo e das Moirai, o que nos permite associá-lo às problemáticas definidoras da tragédia grega ${ }^{28}$. É pois ao flamenco que Mur Oti recorre como música de fundo em alguns planos, como que acentuando a tonalidade trágica da sua história. É por isso também sintomático que, ao ouvir a música, Fernando se sinta particularmente incomodado.

Tal como o filme de Dassin, este é um drama de emoções ${ }^{29}$. E se aquele foi acusado de se ter tornado um drama burguês, mais preocupado com as aparências e os costumes das famílias socialmente bem colocadas do que com as tensões dramáticas que ultrapassam as personagens próprias da tragédia, também o filme de Mur Oti padece, em parte, da mesma enfermidade, ao centrar-se no triângulo amoroso constituído por um pai, um filho e uma madrasta, desprezando o fator divino transcendente às capacidades humanas. Há, contudo, elementos que de certo modo acabam por funcionar de forma mais eficaz em convergência com o trágico, como a inocência de Estrela, pois o adultério incestuoso não chega a consumar-se, como pensam as mulheres da praia, ou a "abstinência" de Fernando. Neste sentido, esta deverá ser, de todas as produções cinematográficas, a que está mais próxima dos textos antigos.

A culpa desta Fedra está em avançar de forma interesseira para um casamento sem amor, com o único objetivo de se aproximar daquele que ama. Esta deverá ser uma das grandes diferenças em relação aos textos antigos, onde as razões que Fedra evoca para amar Hipólito, além da força divina de Afrodite em Eurípides, são o seu não amor por Teseu, a ausência do marido e a constante infidelidade do mesmo ${ }^{30}$. Estas razões nem sequer são compatíveis com o amor que Juan mostra ter por Estrela e o mesmo pode dizer-se, em parte, acerca de Thanos e Fedra no filme de Dassin (sentirá Fedra falta do amor de Thanos?). Com efeito, a paixão incontrolável e degradante da personalidade funciona

\footnotetext{
${ }^{28}$ Neste sentido, seria eventualmente interessante estudar a possível relação entre o fado na cultura portuguesa, o flamenco na cultura espanhola e o trágico, em particular os coros, na cultura grega. Curiosamente, que saibamos, poucos têm estabelecido essa relação, em particular no que diz respeito ao fado.

${ }^{29}$ Apesar de se verificarem opções comuns nos dois filmes, a verdade é que não sabemos se Dassin teria tido conhecimento do filme de Mur Oti. Mas não é improvável.

${ }^{30}$ Razões já aduzidas por M. C. Pimentel 1987: 261.
} 
aqui como esse tal fator divino que dava consistência à tragédia euripidiana e a cujo processo de secundarização Séneca deu início. A diferença está sobretudo na absolvição do divino como causa desse comportamento. $\mathrm{Na}$ sequência do "estilo" do estoico latino, o ódio emerge a seguir à paixão não correspondida, o que acaba por precipitar a tragédia. Convém por isso recordar que Séneca é apresentado nos créditos do filme como o grande inspirador do argumento de Mur Oti.

O final retoma a poética do mar e morte, com o suicídio de Estrela e o fim de Fernando ${ }^{31}$. As formas são distintas, mas a funcionalidade continua a ser senequiana: a morte continua a ser a única via para se manterem unidos para sempre. Tal como acontece na Fedra de Séneca, também aqui o suicídio da protagonista é o único caminho ao seu alcance e "o último - o único - ato de amor entre Fedra e" Fernando (M. C. Pimentel 1987: 268).

\section{Abby/Ana e Eben Cabot: uma Fedra com tiques de Medeia; um Hipólito de rasgo edipiano}

Desire under the Elms é uma peça de teatro norte-americana, escrita e publicada por Eugene O’Neill em 1924, cuja ação se passa em Nova Inglaterra, em 1840. O enredo baseia-se no mito de Fedra e Hipólito, aqui metamorfoseados nas figuras de Abbie Putnam e Eben Cabot. Na verdade, mantém-se uma opção que se reconhece também em outras obras de O'Neill, como Mourning becomes Electra, em que a ação mitológica grega é transferida para aquele que é considerado por muitos o tempo mítico da cultura norte-americana.

Eben é o filho mais novo do viúvo Ephraim Cabot, o qual, tendo deixado a sua quinta aos três filhos, acaba por regressar à mesma, mas trazendo consigo Abbie, uma jovem madrasta para os rapazes. Graças a uma artimanha, Eben rouba o pai e compra aos meios-irmãos as respetivas parcelas na quinta, que sente sua por direito. Este motivo é, aliás, entroncado no tema mitológico da rocha, associado à figura de Teseu, e tem uma forte conotação bíblica, designadamente com o tema de Jacob e Esaú e respetiva venda de primogenitura (Gn 25.29-34). À boa maneira norte-americana, aliás, o bíblico não deixa de estar presente. O tema do regresso do filho pródigo é igualmente evidente no retorno dos filhos recém-casados à casa do pai que, em festa, comemora um quarto filho recém-nascido, mas que a populaça crê ser devido a Eben e não a Ephraim. Por outro lado, O'Neill rejeita outros motivos, como o da castidade de Hipólito, uma vez que Eben assume comportamentos que

${ }^{31}$ F. Salvador Ventura 2008: 508 refere que o filme se estreou com um final alternativo, ainda que mantendo a morte dos heróis no final. A censura, porém, interveio e o final teve de sofrer ligeiras alterações. 
se coadunam pouco com essa diretriz. É ao perceber que desperta o desejo no enteado, por exemplo, que Abbie avança para a sedução. $\mathrm{E}$ as diferenças não se ficam por aí. Ao contrário do Hipólito euripidiano ou mesmo do senequiano, Eben reivindica uma personalidade ambiciosa e ardilosa, algo freudiana mesmo, na relação que parece manter com a memória evocada da mãe. Essa tonalidade psicanalítica percebe-se também no ambiente opressivo que se vive na casa dos Cabot, particularmente expressa pela relação dos filhos com o pai, que acabará por conduzir à hipótese de matar o próprio pai. Além disso, é o desidério da posse da terra que se destaca como o tema catalisador da tragédia, e não o problema do religioso. Paradoxalmente, isso faz de Eben uma figura profundamente telúrica. Esta opção corresponde, como é evidente, às diferenças epocais que justificam os rumos alternativos na definição do trágico. Por outro lado, o egocentrismo que se reconhece na personagem de Perkins parece dever algo a Eurípides e a Séneca.

As tonalidades psicoanalíticas são profundas neste drama ${ }^{32}$. Se Eben se apresenta como uma espécie de Édipo, já Abbie passará por ser um tipo de Medeia. Ao dar à luz uma criança que acaba por se revelar um obstáculo à manutenção da sua relação adulterina com o enteado, opta pelo mais vil dos caminhos, ao assassinar o próprio filho. Nesse momento, o caráter de Abbie passa a identificar-se com a figura de Medeia, sendo que o sentimento amoroso continua aqui válido como móbil do hediondo crime. Após a rejeição, porém, Eben chama a si um traço de humanismo comovente, ao entender a atitude de Abbie e as razões para a sua loucura. Os amantes confessam-se perante o marido enganado que resiste a matá-los e prefere entregá-los ao braço armado da justiça, qual bom cidadão norte-americano. Mas não deixou de ser a cegueira de Eben, uma vez mais edipiana ao mesmo tempo que sintomática do seu narcisismo, que o conduziu à sua própria tragédia. E o seu castigo nemésico, bem como o da sua cúmplice amorosa, passa por viver o remorso do homicídio do próprio filho e a eventual forca como desenlace final. De certo modo, todavia, há alguma felicidade para o casal enamorado, que acorda o destino comum.

O'Neill representa uma nova expressão na dramaturgia norte-americana contemporânea. Quando em 1958 Delbert Mann adaptou a peça ao cinema estava por certo preocupado, em primeiro lugar, com a versão do texto de O’Neill, aqui adaptada por Irwin Shaw. Mas é evidente que o substrato clássico do enredo do mesmo se destaca sobre qualquer outro tópico e é impossível

${ }^{32}$ J. Glenn 1976 considera mesmo que essas tonalidades remontam ao próprio Eurípides, que não teria necessitado de um Freud para se aperceber da tensão inerente às mesmas. $\mathrm{O}$ simbolismo sexual, por exemplo, está presente nas falas da Fedra euripidiana com particular acentuação. 
assistir a Desire under the Elms sem ter como premissa os textos de Eurípides e de Séneca. Na verdade, o próprio título da peça norte-americana evoca um verso do dramaturgo grego, reclamando desse modo e de forma inequívoca a origem clássica do tema (Eur., Hipp. 208-211; cf. Sen., Phaed. 10).

Para esta adaptação, Mann foi buscar algumas estrelas do sistema cinematográfico americano, como Burl Ives, magnífico como Ephraim Cabot, e Anthony Perkins. Com esta prestação, aliás, Perkins abria caminho para a sua interpretação do Alexis/ Hipólito de Dassin quatro anos mais tarde, o que também viria a contribuir para a sua transformação no "Hipólito" do cinema por excelência. Para interpretar Abbie, o realizador escolheu uma figura que, na época, estava a debutar no cinema norte-americano: Sophia Loren. A origem italiana da atriz, todavia, levou a uma mudança no argumento original, transformando a "Abbie Cabot" de O’Neill numa “Ana”, empregada de mesa italiana, imigrante nos EUA, cuja sorte muda quando encontra Ephraim Cabot.

\section{Fedra no Western}

Como assinalámos, vários autores têm salientado o papel mitológico que o western representa na cultura norte-americana, essencialmente derivado do caráter fundacional que define esse género cinematográfico. Talvez por isso também se torne duplamente pertinente a adaptação do mito de Fedra e Hipólito a um cenário western, como acontece com Fedra West, filme rodado em 1968, sob a direção de Joaquín Luis Romero Marchent. Apesar de falado em inglês, a cultura hispano-mexicana subjaz também a esta produção, dado que o enredo se localiza nas regiões fronteiriças do México com os EUA. Este fator levou a que o filme em causa fosse considerado um western spaghetti, género que teve o seu acme precisamente nos anos 60 do século $X X$ e que está para o western clássico como o peplum está para o filme dito épico. Outro aspeto a salientar é o facto de a atriz titular ser a brasileira Norma Bengell, particularmente conhecida nessa época.

Bengell interpreta Wanda, uma mexicana de origens humildes que desposa D. Ramón (James Philbrook), um rico fazendeiro, que controla a economia local. Ramón tem um filho de uma primeira mulher, Stuart (Simón Andreu), que regressa a casa depois de ter terminado medicina numa Universidade de Filadélfia. A mãe de Stuart era norte-americana o que justifica o nome anglo-saxónico do rapaz. A chegada de Stuart vem alterar o rumo dos acontecimentos. Apesar de se considerar bem casada, Wanda não resistirá à paixão pelo enteado, a qual se sucede a um ódio prévio deste por aquela. Com efeito, Stuart considera Wanda a usurpadora do lugar da sua mãe. Mas será a paixão incestuosa que acabará por desencadear a tragédia na família. $\mathrm{O}$ casamento feito por interesse monetário não deverá ser também estranho a 
esse desenlace.

A mera enunciação das personagens centrais do filme permite perceber que uma vez mais estamos perante uma história cuja estrutura assenta no mito de Fedra e Hipólito: Wanda é Fedra e Stuart é Hipólito, enquanto D. Ramón é Teseu, um rei à sua maneira. A mãe de Stuart assume o papel de Antíope/ Hipólita/ Melanipe e até a supersticiosa ama índia de Wanda sugere os enredos da tragédia antiga. Apesar do setting, são vários os elementos que evocam o mito antigo e respetivos significados, como a omnipresença dos cavalos, e, em particular, o afeto que Stuart demonstra por eles - é através deles que, no final, tenta fugir à ira do pai -, cuja importância neste contexto foi já enunciada. Por vezes, os símbolos transferem-se para as formas consideradas mais adequadas no seu enquadramento, como o deserto que assume as funções do mar/ floresta na tradição antiga. Outros topoi clássicos, não necessariamente trágicos, são reconhecíveis de modo fácil, como o da tempestade que se abate sobre os amantes e os obriga a resguardarem-se num local que favorece a paixão (Verg., Aen. 4.130-197) ou ainda o da cena voyeuse do tipo da do banho de Ártemis, em que o jovem é seduzido pela nudez da mulher enquanto a observa a banhar-se. Como assinalámos, esta temática está igualmente presente na Fedra de Mur Oti.

Tal como as produções antes referidas, porém, também esta adaptação prescinde de qualquer elemento metafísico que promova a paixão entre madrasta e enteado, preferindo, em vez disso, colocar a sílaba tónica na reciprocidade dos sentimentos dos protagonistas do adultério. Este pormenor, todavia, como afirmámos, não é de somenos na economia do enredo, uma vez que permite que a história resvale o melodrama burguês, mais ao gosto do público contemporâneo, afastando-se da conceção original, tal como foi definida pelos trágicos greco-latinos, em particular por Eurípides. Do mesmo modo, a introdução da personagem do irmão de Wanda, que acelera o desenrolar do drama através da ameaça de delação do adultério ao marido traído, que, todavia, acaba por se concretizar na pessoa da própria Wanda/ Fedra, é uma novidade em relação às tradições antigas.

Já a confissão do adultério, presente também nos filmes de Dassin e de Mann, contrapõe-se ao antigo motivo da mentira, presente apenas na versão de Mur Oti. Como vimos, também só aí a "inocência” de Hipólito é preservada. Igualmente comum às restantes versões é a deterioração da relação entre madrasta e enteado. Esta opção preenche a necessidade de criar a antinomia entre ambas as personagens e caracteriza a essência da tragédia antiga. Pois o facto é que, à exceção da Fedra espanhola, todas as versões cinematográficas são incapazes de resistir à consumação do adultério incestuoso, eventualmente a forma dramática mais atraente para as audiências hodiernas e que coloca a possibilidade da metamorfose da tragédia em melodrama. $\mathrm{O}$ auto-desprezo de Stuart, por outro lado, reconhecida também em Alexis Kyrillis e em 
Eben Cabot, corresponde à desintegração psicológica de Hipólito tanto em Eurípides como em Séneca. Outra novidade nesta Fedra West é o facto de ser Rámon/Teseu quem acaba por 'sujar' as mãos de sangue ao matar mulher e filho, forçando desse modo a aplicação do castigo aos amantes, pela opção errada que tomaram.

\section{Outras Fedras, outros Hipólitos}

O tema de Fedra e Hipólito foi ainda tratado em três outras produções. Em 1957, George Cukor, realizador especialmente conhecido pelo valor que dava às atrizes/ figuras femininas nos seus filmes, rodou Wild is the Wind, filme baseado no romance de Vittorio Nino Novarese, com argumento escrito por Arnold Schulman. Para protagonizar o filme, Cukor chamou duas das estrelas da época: o ator mexicano Anthony Quinn, que viria a celebrizar-se em várias fitas, como o épico Barabbas (1961) e o não menos famoso Zorba, the Greek de Cacoyannis (1964); e a italiana Anna Magnani, que na ocasião estava a tornar-se um caso sério de popularidade nos EUA, mercado cultural que, como é sabido, não é particularmente fácil para outras línguas que não o inglês ${ }^{33}$.

Neste filme, Quinn encarna o caráter de Teseu. A sua personagem é Gino, um imigrante viúvo bem sucedido, que decide casar-se pela segunda vez com Gioia (Anna Magnani), a irmã da primeira mulher. Para isso, decide ir buscá-la a Itália e trazê-la para os EUA. Gioia é claramente a recriação de Fedra, irmã de uma Ariadne/ Rossana que antes ocupara o coração de Gino. A família de Gino integrou-se na sociedade americana e, através da inadaptação à nova realidade, a recém-imigrada Gioia vem reavivar a memória da família do caráter estrangeiro das suas origens. Gino vive com um irmão e uma cunhada, numa zona rural dos EUA, e é pai de uma rapariga, Angie (Dolores Hart), o que, à partida, sugere uma rutura com o mito original. Mas a presença de Bene (Anthony Franciosa), a quem Gino ama como a um filho e que é o alvo do amor de Angie, permite a recuperação da ideia original, pois será em Bene que Gioia acabará por concentrar as suas atenções e sentimentos. Na verdade, Bene parece ser o único que presta atenção a Gioia, valorizando-a como ela é, enquanto Gino deseja à força que a sua nova mulher seja uma mera réplica da primeira. Até os nomes das duas mulheres ele troca. Teresa (Lili Valenti), a cunhada de Gioia, por sua vez, funciona como o olhar controlador, um misto da antiga ama trágica com a da denúncia do crime passional.

Também neste filme a metáfora do cavalo/ Hipólito é particularmente forte. São as palavras de Gioia, ditas na acentuada pronúncia italiana da

${ }^{33}$ A interpretação de Magnani foi considerada exagerada por alguns dos críticos deste filme. Não concordamos com esta opinião, uma vez que a atriz encarna bem o espírito mediterrâneo e em particular o efusivo caráter italiano. 
personagem, que mais facilmente retemos e que se revelam carregadas de simbolismo. Diz a italiana ao marido, na sequência do avistamento dos cavalos selvagens e do fascínio erotizante que a manada provoca na mulher: "I am crazy about horses". A recusa em domar o cavalo selvagem, pelo pavor que a eventual inflição de sofrimento no animal lhe causa, só é plenamente entendida se tivermos em conta o mito original de Hipólito ${ }^{34}$. A figura do cavalo está ainda presente em outras situações, designadamente entre os objetos que decoram a casa de Gino.

Mas as diferenças com as outras propostas são também evidentes. Cabe ao Hipólito desta história avançar para a confissão da paixão proibida à mulher amada. Ao contrário da versão de Dassin, por exemplo, o "agressor" é aqui o jovem e não a mulher. Mas ainda assim é Bene a personagem que se identifica com o herói antigo, uma vez que as funções que assume são as correspondentes às do filho de Teseu. A sua relação com Gino torna o adultério praticamente incestuoso. Por momentos, ficamos mesmo com a impressão de que, se Bene não avançasse, Gioia jamais descobriria em si a atração pelo jovem. $\mathrm{O}$ que provavelmente até corresponde à ideia original do argumento, pois é esse despertar que mostra a Gioia a compensação alternativa para a falta de atenção do marido. Por outro lado, há momentos em que se sugere um certo homoerotismo entre os dois homens que, contudo, poderá não passar de uma mera impressão exagerada pelo hermeneuta. Tal como acontece com a personagem de Ercy no filme de Dassin, a Angie desta película parece ser uma recuperação da versão raciniana do mito antigo e da figura de Arícia.

Só após a descoberta do adultério, Bene manifesta repúdio pelo ato que cometeu. Mas o mais original desta produção, eventualmente mais próxima das conceções de Séneca do que das de Eurípides, é a reconciliação final de marido e mulher, em total contrariedade às vias do mito antigo. Mas a verdade é que é neste final, sintetizado na frase proferida por Gioia, "I need someone who loves me", e na domesticação do cavalo selvagem, que melhor se reconhece o melodrama americano, típico do período desta produção e tão bem representado por Cukor na história do cinema. A opção de transformar Bene num "mero" amigo da família em vez de fazer dele filho de Gino corresponde igualmente a esse espírito, diminuindo a tragicidade original do enredo mas confortando a moralidade burguesa da sociedade norte-americana dos anos 50 do século passado.

No ano anterior a esta produção, em 1956, Robert Wise dirigira Tribute to a bad man, um western baseado num conto de Jack Schaefer, com James Cagney, Don Dubbins e a grega Irene Papas, nos principais papéis. Esta é a história de Jeremy Rodock (Cagney), um "senhor do wild west", que mantém

\footnotetext{
${ }^{34}$ Sobre o erotismo do tema em Eurípides, ver J. Glenn 1976.
} 
uma relação amorosa com uma imigrante grega, apropriadamente chamada Jocasta Constantine, mas conhecida simplesmente como "Jo" (Papas). A chegada do jovem Steve Miller (Dubbins) à região, porém, vai trazer a perturbação do equilíbrio amoroso. A forma como se estabelecem as relações entre as personagens sugere a estrutura do mito grego de Fedra e Hipólito e a escolha de Papas, que viria a celebrizar-se internacionalmente nos papéis de Antígona, Electra, Helena e Clitemnestra ${ }^{35}$, pretendia por certo acentuar essa perspetiva. Além disso, o recurso ao western voltava a vincular o tema grego aos motivos fundacionais da cultura norte-americana ${ }^{36}$. Mas a ausência de laços de sangue e de família na história fazia com que esta voltasse a reincidir mais na estratégia do melodrama do que na da tragédia. Do antigo ciclo mitológico ficava apenas a paixão da jovem mulher pelo rapaz particularmente ligado ao marido daquela. Mais ainda: o final, que reivindica a reorganização do cosmos com que deparamos no início da película - a jovem mulher preserva a sua relação com o velho Roddock enquanto o rapaz regressa ao seu caminho, assumindo a paixão vivida como um mero devaneio amoroso da juventude sem quaisquer consequências - castra também qualquer eventual intencionalidade ao nível da identificação com a antiga história grega.

A terceira película dedicada ao mito de Fedra e Hipólito data de 1968. Trata-se essencialmente da versão cinematográfica de peça de Racine, Phèdre, realizada por Pierre Jourdan. Enquanto nas restantes produções não existe qualquer confusão entre teatro e cinema, neste caso verifica-se precisamente o oposto (Cf. K. MacKinnon 1986: 97). Este filme é, portanto, teatro filmado, que conta com a majestosa interpretação de Marie Bell, famosa atriz da Comédie Française, no papel titular, apesar da já evidente idade avançada da intérprete para a personagem que representa. Ainda assim, Bell consegue ser credível como Fedra e oferece como ninguém à personagem a postura sofrida que se exige à rainha de Trezena, enquanto Claude Giraud compõe um convincente Hipólito de aura solar. Não nos vamos centrar nas diferenças estéticas e poéticas do texto de Racine em relação a Eurípides e a Séneca, dado que não é esse o nosso objetivo e que o assunto foi neste volume tratado por Marta T. Anacleto (pp. 83-91). Mas são precisamente essas diferenças que transparecem nesta produção, como seria de esperar, apesar de a adaptação de Jourdan nem sempre seguir de forma linear o texto do poeta setecentista, chegando mesmo a eliminar alguns versos e passos. Também esta é uma tragédia de emoções e como tal centra-se sobretudo nos sentimentos das figuras que a protagonizam. Mas isso não levou ao desprezo

35 Filmes de Yorgos Javellas (1961) e de Michael Cacoyannis (1962, 1971, 1977), respetivamente.

${ }^{36}$ Valerá a pena referir que a relação entre o western e a tragédia foi particularmente ensaiada em High Noon, de Fred Zinnemann (1952), com Gary Cooper e Grace Kelly nos principais papéis. 
das restantes funcionalidades de encenação. As opções e estratégias cenográficas, como as da composição do guarda-roupa, seguem naturalmente a estética barroca, evocando os ambientes antigos, mas sendo claramente marcadas pelo tempo da criação do texto. A preocupação com a perspetiva dos grandes espaços é evidente, a qual alterna com significativos close-ups. A fotografia reforça estas características, conferindo ao filme um tom onírico que remete para o mito ocorrido in illo tempore. Eventualmente, é a imagética de Poussin que domina a fotografia do filme.

Em 2009, esta peça foi de novo levada à cena, sob a direção de Nicholas Hytner e com as aplaudidas interpretações de Helen Mirren (Fedra), Dominic Cooper (Hipólito), Stanley Townsend (Teseu) e Margaret Tyzack (Enone). A encenação fez parte de um projeto do teatro nacional do Reino Unido e foi gravada e apresentada em vários cinemas ingleses e do resto do mundo. Apesar de não ser uma produção cinematográfica, portanto, esta Fedra não deixou de passar pelo cinema. A peça foi ainda apresentada no Epidauro, em 2009, num festival de teatro clássico, onde alcançou um êxito retumbante ${ }^{37}$.

\section{Excurso: Fedra no Peplum}

A figura de Fedra fez história no cinema sobretudo enquanto personagem derivada da tragédia. Levada ao setting através das propostas analisadas, essa opção não foi, porém, exclusiva. Efetivamente, a história de Fedra, enquanto personagem da parte do mito de Teseu sediada na corte de Minos, poucas vezes é mencionada. Em particular os eventos na sequência dos quais acaba por se casar com o jovem ateniense. Sabemos que, segundo umas versões, a princesa teria sido dada em casamento ao herói do Norte, e, segundo outras, a instigadora do abandono da irmã em Naxos com o objetivo de desposar o vencedor do Minotauro (Ov., Her. 4; Apollod. 3.1-4; 15.8). Conhecem-se variantes desta faceta do mito. Mas, seja como for, não tem sido este o vetor principal dos tratamentos da figura de Fedra. A preferência tem-se concentrado no drama já gerado na casa da rainha de Trezena, o que deriva sobretudo da influência da tragédia antiga.

${ }^{37}$ Alguns autores têm sugerido também que o romance de Colleen McCullough, The Thorn Birds, publicado em 1977 e adaptado para televisão em 1983 por Carmen Culver, seria baseado no mito de Hipólito. O elenco era constituído por uma mão-cheia de "estrelas" como Richard Chamberlain, Rachel Ward, Barbara Stanwyck, Christopher Plummer, Jean Simmons, Richard Kiley e Piper Laurie. A história de um padre, obrigado ao celibato, que se apaixona por uma mulher poderá evocar o tema de Hipólito, mas talvez esse argumento não seja suficiente para se estabelecer uma relação tão próxima. De igual modo, a telenovela Rainha da Sucata, da autoria de Sílvio de Abreu, exibida pela brasileira Rede Globo em 1990, tinha como enredo de base o tema da madrasta (Glória Menezes) que se apaixona pelo enteado (Tony Ramos), recriando no pequeno ecrã o motivo de Fedra e Hipólito. 
Existe, todavia, um filme de 1960, que se insere num género conhecido como peplum, que aborda essa vertente do mito ${ }^{38}$. Trata-se de Teseo contro il Minotauro, uma produção italiana dirigida por Silvio Amado, com argumento de Gian Paolo Callegari e Sandro Continenza.

O centro do enredo é o mito de Teseu enquanto herói do labirinto de Creta e vencedor do Minotauro. Como é prática no peplum, não são grandes as preocupações com o rigor histórico ao nível da cenografia, do guarda-roupa ou até mesmo da criação de algumas personagens. Isso não significa, porém, que o filme não se construa através de um ambiente que o torna credível enquanto cinema sobre a Antiguidade e, neste caso em concreto, sobre a civilização minóica. Por essa razão, a lenda de Teseu e Ariadne dilui-se aqui ao serviço das funcionalidades do peplum. Surge por isso uma rainha pérfida, que poderá evocar a antiga Pasífae, mas que reivindica o nome e o figurino de Fedra. Esta Fedra (Rosanna Schiaffino) é ainda gémea de Ariadne (interpretada pela mesma atriz) que, essa sim, se mantém como a amada de Teseu (Bob Mathias) e que por isso mesmo se transforma no alvo a abater por parte da pérfida soberana. Apesar da reminiscência clássica, o enredo só vagamente se assemelha ao que os antigos textos contam. As outras personagens do mito, como a própria Pasífae (Tina Lattanzi), Minos (Carlo Tamberlani) ou Egeu (Nerio Bernardi), são praticamente inócuas no desenrolar da história. Em contrapartida, criam-se outras, com base na memória dos jovens atenienses sacrificados anualmente ao monstro de Creta. E a figura do Minotauro (Milo Malagoli) é ridícula, porquanto recorda mais o King Kong do que o monstro mitológico. Por vezes, o enredo resvala o sado-masoquismo, como acontece com a cena da câmara das torturas da rainha, na qual Teseu acaba por se encontrar prisioneiro. $\mathrm{O}$ desenlace do filme é, obviamente, original em relação ao que conhecemos das várias versões do mito antigo. $\mathrm{O}$ curioso a salientar é que, seguindo a via aqui proposta, perdemos matéria que possibilite a construção da tragédia de Fedra, Teseu e Hipólito, tal como a conhecemos. Enfim, nada de anormal no reino do

${ }^{38} \mathrm{O}$ peplum é um filme por norma de origem italiana, cuja temática anda em torno de um episódio ou uma personagem da Antiguidade, mas que não constitui propriamente uma superprodução cinematográfica. O peplum ficou também conhecido como "filme de túnica e sandália", por oposição aos de "capa e espada", em que o principal atributo do ator titular - por norma um atleta famoso - é o físico musculado. Os pepla foram muito populares nos anos 50-70. A. Collognat define o género do seguinte modo: o peplum inclui "uma tipologia de personagens" que dão corpo a filmes de série B; estes são "menos célebres do que as superproduções hollywoodescas..., menos inspiradas do que as obras-primas da sétima arte, como as adaptações de Pier Paolo Pasolini, Michaël Cacoyannis ou Federico Fellini, mas realizadas para o ecrã a partir da literatura antiga. Um número considerável destes modestos pepla italianos podem no entanto oferecer uma excelente ocasião para a reflexão sobre a receção moderna de um tema antigo". Em termos simplistas, o peplum tem funções e opções narrativas muito semelhantes às do antigo romance grego. Sobre esta questão ver V. Attolini 1991: 453-461; M. Salotti 1997; A. Collognat 1998: 64; N. S. Rodrigues 2010: 151, 166-167. 
peplum. Mas, em justiça, há que notar que o público deste tipo de filmes estaria muito por certo pouco preocupado com a eliminação de tão sublime destino.

\section{Notas finais}

Desta exposição destaca-se o facto de o tema da Fedra trágica ser o que maior presença tem no cinema, em detrimento da Fedra do ciclo cretense. Ainda assim, nos primeiros anos de existência do cinema, as tentativas de adaptar tragédias gregas, e em particular a do tema de Fedra e Hipólito, foram escassas e pouco significativas. Essa opção só se viria a verificar entre os anos 50 e 70 do século passado.

Comum à quase totalidade dessas adaptações - a exceção é a Phèdre de Jourdan, mas nesse caso está-se no domínio do teatro filmado - é o facto de se adotar uma postura estruturalista, em que o adaptado é a estrutura do mito antigo, centrado na relação de um homem, a sua mulher e um jovem, que por norma até é filho dele e enteado dela. Não obstante, reconhecemos-lhe a inspiração euripidiana, senequiana e até mesmo raciniana. De notar todavia que, mesmo entre os dramaturgos, incluindo os antigos, se verificavam variantes do mito, mantendo-se contudo a sua estrutura fundamental.

Com efeito, a tendência é para transportar o mito original para contextos modernos, sejam eles o da América do final do século XIX, seja o da Grécia dos anos 60 do século XX. Este processo, porém, levou também ao que alguns autores chamam de melodramatização da tragédia, em que os valores da decência burguesa se sobrepõem aos planos diretores do trágico, tal como Aristóteles os terá definido, designadamente a intervenção divina e o estatuto subordinado dos homens perante os desígnios dos deuses ou de forças como a moira. Apesar disso, reconhecem-se ali outros elementos, como a bybris ou o dilema trágico em algumas das personagens. Por outro lado, o livre-arbítrio de algumas delas acaba por minar o substrato trágico. Mas há que referir que estas opções vêm na continuidade de conceções dramáticas já identificáveis em autores como Séneca, onde o desígnio divino dá, em grande parte, lugar aos conflitos provocados pelas paixões da alma ${ }^{39}$. Neste sentido, os filmes sobre Fedra, incluindo o de Dassin que se pressupõe euripidiano, são sobretudo senequianos.

Impõe-se explicitar que a tendência para a modernização do teatro trágico corresponde a um processo possível apenas porque nele se reconhece uma universalidade de problemas que se revela transversal ao nível cultural

${ }^{39}$ Como nota M. C. Pimentel 1987: 264, “enquanto no Hippolytos de Eurípides são os deuses que motivam as ações e desencadeiam a tragédia, em Séneca, à boa maneira estoica, tudo se passa ao nível do ser humano, o bem e o mal, o conflito e os erros. São os homens que se perdem pelas suas ações”. 
e temporal - como a paixão, o ciúme, a traição - e não o transitório. Outra leitura viável é o facto de essas opções serem, eventualmente, mais atraentes para o público contemporâneo (cf. M. M. Winkler 2001: 74). Deste modo, as personagens destes filmes transformam-se no que Salvador Ventura chama de avatares da tragédia antiga (F. Salvador Ventura 2008: 521). Na verdade, já os trágicos antigos haviam processado algo de semelhante, ao conferirem às suas criações o que consideravam pertinente e relevante para o seu tempo. I.e., ontem como hoje, os mitos têm sido transpostos e reinterpretados de acordo com as pertinências de cada tempo e sociedade. Estamos, portanto, perante uma realidade cultural em construção.

Perante os filmes que nos chegaram, reconhecemos ainda outro elo comum a todos eles: o Mediterrâneo. Este elemento está presente inclusive no western, onde a origem hispano-italiana de algumas personagens remete para esse horizonte cultural.

Resta-nos salientar ainda um certo pioneirismo na versão espanhola de Fedra, em particular em relação ao filme de Dassin. A proposta de Mur Oti é a mais fiel aos textos antigos, em particular a Séneca, com a preservação dos valores das personagens e as idiossincrasias correspondentes, como são a castidade de Hipólito e a engendração da mentira da madrasta. Quase todas as Fedras cinematográficas caem pela falta de atenção do marido, quando não mesmo pela inadequação no seio do casal. A exceção cabe à versão espanhola, na qual a respetiva Fedra avança antecipada e interesseiramente para um casamento oportunista, motivada pelo desenfreio da paixão pelo homem errado. Por outro lado, talvez Hipólito seja a personagem que mais varia nestas releituras do mito. $\mathrm{Na}$ maioria dos casos, só a cedência do jovem à carnalidade insinuada da madrasta dá lugar ao remorso que acaba por assumir as antigas formas misóginas. Talvez esta seja a maior evidência das exigências da modernidade nestas adaptações. Uma vez mais, a exceção verifica-se de novo no filme espanhol. De igual modo, não será demais referir que a ousadia e o mérito de apresentar um Hipólito com uma orientação sexual heterodoxa, que justifica a sua atitude de rejeição e confere solidez ao caráter da personagem, numa época em que todas essas problemáticas eram um tabu sério, coube igualmente ao cinema de língua castelhana. 